\title{
Freeze-Thaw Behavior of Stabilized Clayey Soil with Red Mud and Cement
}

\author{
Ekrem Kalkan \\ Department of Civil Engineering \\ Engineering Faculty \\ Ataturk University \\ Erzurum, Turkey
}

\begin{abstract}
The clayey soils in areas with seasonal frost are exposed to at least one freeze-thaw cycle every year and worsen their engineering properties. To prevent the engineering properties of clayey soils, it is necessary to improve the freeze-thaw resistance of them. In this study, the clayey soil was stabilized by using red mud and cement additive materials. Prepared samples of clayey soil and stabilized clayey soil were subjected to the unconfined compressive test. To investigate the effects of red mud and cement additive materials on the freeze-thaw resistance of clayey soil, the natural and stabilized expansive soil samples were exposed to the freezethaw cycles under laboratory conditions. The obtained results showed that the red mud and cement additive materials increased the freeze-thaw resistance of clayey soil. Consequently, it was concluded that red mud and cement additive materials can be successfully used to improve the freeze-thaw resistance of clayey soils.
\end{abstract}

Keywords: Clayey soil, red mud, cement, unconfined compression strength, freeze-thaw

\section{INTRODUCTION}

The clayey soils are generally classified as expansive soils and these soils are known to cause severe damage to structures resting on them. However, these soils are very important in geology, construction, and for environmental applications, due to their wide usage as impermeable and containment barriers in landfill areas and other environmentally related applications (Erguler and Ulusay, 2003; Harvey and Murray, 1997; Kayabali, 1997; Keith and Murray 1994; Murray, 2000; Sabtan, 2005; Kalkan and Akbulut, 2004; Kalkan et al., 2019; Indiramma et al., 2020; Yarbaş1 and Kalkan, 2020).

The effects of freeze-thaw cycles on the geotechnical properties of clayey soils were studied (Lee et al., 1995; Eigenbrod, 1996; Konrad, 2000; Simonsen and Isacsson, 2001; Simonsen et al., 2002; Zhang et al., 2004; Kalkan, 2009). It was seen as a reason of such behavior in low freezing rate, pre-consolidation pressure developed during freezing, formation of new bonding between soil fabric units, and changes in free water (Broms and Yao, 1964; Yong et al., 1985; Eigenbrod, 1996; Yang et al., 2003; Kalkan, 2009). These changes are attributed to increased saturation with water caused by freezing and thawing, but much of the increase is attributed to changes in soil structure (Chamberlain et al., 1990; Porebska, 1994; Kalkan, 2009; Yarbaşı and Kalkan, 2021).

When the mechanical qualities of expansive soils are lower than those required, stabilization can be an option to improve performance, notably in enhancing its strength. Improvement of certain desired properties like bearing capacity, shear strength and permeability characteristics of soils can be undertaken by a variety of ground improvement techniques such as densification, reinforcement and stabilization (Kalkan, 2012; Lasaki et al., 2018). Soil improvement techniques can be classified in various ways, for example, mechanical, chemical, and physical stabilization (Ingles and Metcalf,
1977; Lambe and Whitman, 1979; Chen, 1988; Chu et al., 2009; Naeini and Mahdavi, 2009; Manar et al., 2015).

In the mechanical stabilization, the soil density is increased by the application of mechanical forces in the case of surface layer compaction. Chemical stabilization includes incorporation of additives such as natural soils, industrial byproducts or waste materials, and cementitious and other chemicals. Physical stabilization includes changing the physical conditions of a soil by means of heating or freezing (Naeini and Sadjadi, 2008; Arab, 2019; Yarbaşı and Kalkan, 2019).

Soil improvement techniques may have the disadvantages of being ineffective and expensive. Therefore, new methods are still being researched to increase the strength properties and to reduce the swell behaviors of clayey soils (Puppala and Musenda, 1998). Many investigators have experienced on natural, fabricated, and by-product materials to use them as additive materials for the modification of clayey soils (Aitcin et al., 1984; Nelson and Miller, 1992; Sandra and Jeffrey, 1992; Asavasipit et al., 2001; Prabakar et al., 2003; Kalkan and Akbulut, 2004; Cetin et al., 2006; Kalkan, 2006; Kalkan, 2011; Kalkan et al., 2020).

The objectives of this research were to investigate the effects of red mud and red mud-cement mixtures on the unconfined compressive strength (UCS) values of clayey soil samples and to test the freeze-thaw resistance of stabilized clayey soil samples with red mud and red mud-cement mixtures. The unconfined compressive strength and freeze-thaw tests were carried out in accordance with related standard procedures to achieve these objectives.

\section{MATERILA and METHODS}

\subsection{Clayey Soil}

The clayey soil has been supplied from the clay deposits of Oltu Oligocene sedimentary basin, Erzurum, NE Turkey. It is over-consolidated and it has clayey-rock characteristics in 
Volume 11-Issue 01, 27 - 30, 2022, ISSN:- 2319 - 7560

DOI: 10.7753/IJSEA1101.1004

natural conditions. It is defined as a high plasticity soil $(\mathrm{CH})$ according to the Unified Soil Classification System (Kalkan, 2003; Kalkan and Bayraktutan, 2008; Kalkan, 2018; Kalkan et al., 2019). The grain size distribution was given in Figure 1 .

\subsection{Red Mud}

Red mud used in this study was provided from Etibank Seydişehir Aluminium Plant, Konya, Turkey. It had a density of $28.5 \mathrm{Mg} / \mathrm{m} 3$ and specific gravity of 3.05 . The grain size distribution of red mud was given in Figure 1.

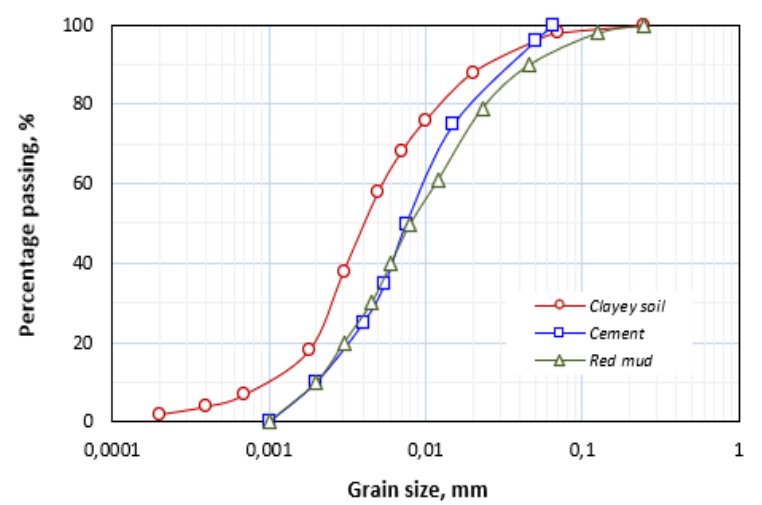

Figure 1. Grain size distribution of clayey soil, red mud and cement

\subsection{Cement}

Cement (PC42.5) used in this study was supplied from a local hardware store in Erzurum, NE Turkey. It had a specific gravity of $\mathrm{Gs}=8.32 \mathrm{lb} / \mathrm{ft} 3(3.13 \mathrm{~g} / \mathrm{cm} 3)$, specific surface of $\mathrm{s}=1496 \mathrm{ft} 2 / \mathrm{lb}(3063 \mathrm{~cm} 2 / \mathrm{g})$, and compressive strength of $\sigma=$ $59 \mathrm{MPa}(590 \mathrm{~kg} / \mathrm{cm} 2)$ at 28 days. The grain size distribution of cement was given in Figure 1.

\subsection{Sample Preparation}

Firstly, clayey soil, red mud and cement were mixed at the required contents under dry condition. Then, amount of optimum water added to the mixtures and blended. The compacted samples were prepared in accordance with Standard Proctor procedure. The samples with $70 \mathrm{~mm}$ high and $35 \mathrm{~mm}$ diameter subjected to the un confined compression and freeze-thaw tests.

\subsection{Unconfined Compressive Test}

The unconfined compression tests were carried out in accordance with ASTM 2166. In this test, three cylindrical samples with a $70 \mathrm{~mm}$ length and $35 \mathrm{~mm}$ diameter were used. The samples were placed in a moist container to prevent from drying while waiting a turn at the compression machine. At least three samples were tested for each combination of variables at a deformation rate of $0.16 \mathrm{~mm} / \mathrm{min}$.

\subsection{Freeze-Thaw Test}

The freeze-thaw tests were performed in accordance with ASTM C 666. All samples were placed in the freezing apparatus and conditioned at $-18{ }^{\circ} \mathrm{C}$. After the freezing was completed, the samples were transferred from the freezing apparatus into a test room at $+20{ }^{\circ} \mathrm{C}$. The freeze-thaw cycle was repeated 20 times.

\section{Results and Discussion}

The effects red mud and cement on the clayey soil were illustrated in Figure 2. It is clearly seen that the red mud and cement played an important role and with the addition of these additives UCS values increased. The effect of the mixtures of red mud-cement on the increase of the UCS value was more than that of the red mud. The increase in the UCS values with the addition of red mud and cement was attributed to the changing composition of the clayey soil. With the addition of red mud and cement to the clayey soil, the particle origin, particle size distribution and surface area of the composite samples changed resulting the increasing in the UCS values (Pera et al., 1997; Attom and Al-Sharif, 1998; Kalkan and Akbulut, 2004; Kalkan, 2006).

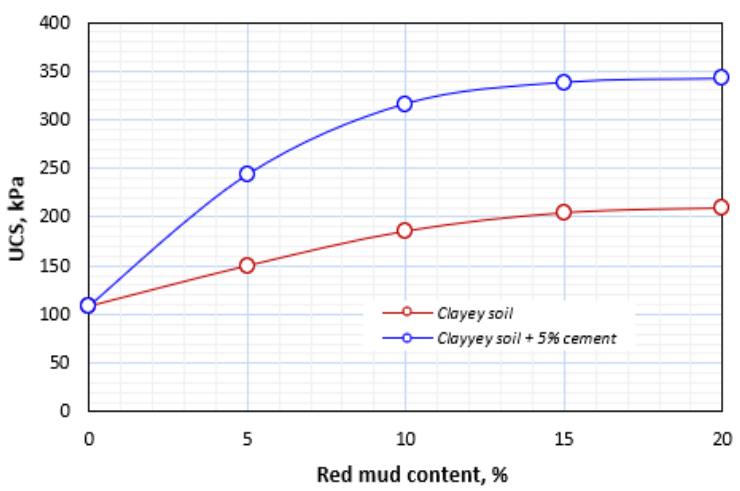

Figure 2. Variation of UCS values with the addition of red mud and cement

To investigate the effects of red mud and cement additive materials on the freeze-thaw resistance of stabilized clayey soil samples, the natural and stabilized clayey soil samples have been subjected to the freeze-thaw cycles. At the end of the freeze-thaw cycles, the natural and stabilized clayey soil samples were tested at the unconfined compression test apparatus under laboratory condition. The effects of the freeze-thaw cycles on the UCS of natural and stabilized finegrained soil samples were shown in Figure 3.

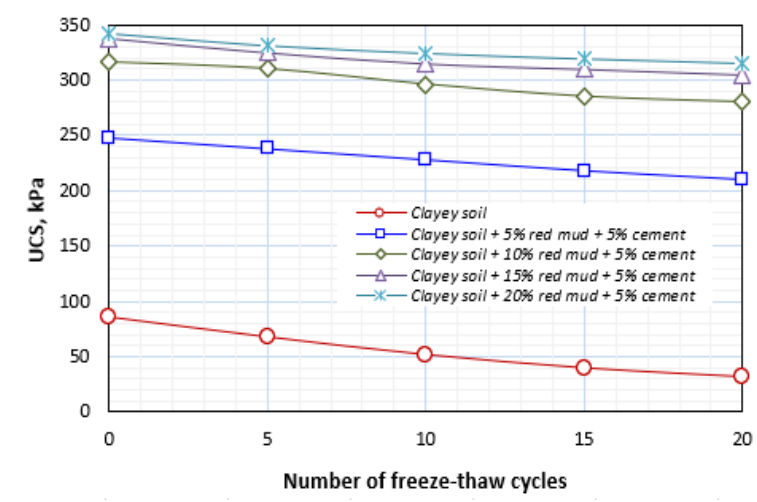

Figure 3. Variation of UCS values with the freeze-thaw cycles

The experimental results show that the red mud and cement additive materials plays a significant role on the freeze-thaw properties of clayey soils. The UCS values of natural and stabilized clayey soil samples are affected by increasing the number of freeze-thaw cycles. However, the red mud and cement additive materials improve the freeze-thaw durability of stabilized clayey soil samples as compared with natural clayey soil samples. The main mechanism governing the alteration of soil behavior caused by the freezing and thawing cycles is believed to be changes in the soil structures 
(Eigenbrod et al., 1996; Viklander, 1997; Viklander and Eigenbrod, 2000; Kalkan, 2009).

\section{CONCLUSIONS}

In this study, the effect of red mud and cement additive materials on the freeze-thaw resistance of clayey soil was investigated. The results showed that the red mud and cement additive materials played an important role on the improving of UCS values of clayey soil. Also, the red mud and cement additive materials increased the freeze-thaw resistance of clayey soil against to the freeze-thaw cycles. As a result, it can be mentioned that red mud and cement additive materials can be successfully used to improve the freeze-thaw resistance of clayey soils.

\section{REFERENCES}

[1] Aitcin, P. C., Ballivy, G., Parizeau, R., 1984. The use of condensed silica fume in grouting. Innovative Cement Grouting. Publication SP-83, ACI Detroit MI, USA, 118.

[2] Arab, M.G., 2019. Soil Stabilization Using Calcium Carbonate Precipitation via Urea Hydrolysis. Proceedings of the 4th World Congress on Civil, Structural, and Environmental Engineering (CSEE'19), April, 2019, Rome, Italy.

[3] Attom, M.F., Al-Sharif, M.M., 1998. Soil stabilization with burned olive waste. Applied Clay Science 13, 219230.

[4] Asavasipit, S., Nanthamontry, W., Polprasert, C., 2001. Influence of condensed silica fume on the properties of cement based solidified wastes. Cement and Concrete Research 31, 1147-1152.

[5] Broms, B.B., Yao, L.Y.C., 1964. Shear strength of a soil after freezing and thawing. ASCE 90 (SM4), pp. 1-25.

[6] Cetin, H., Fener, M., Gunaydin, O., 2006. Geotechnical properties of tire-cohesive clayey soil mixtures as a fill material. Engineering Geology 88 (1-2), 110-120.

[7] Chamberlain, E.J., Iskander, I., Hunsickert, S.E., 1990. Effect of freeze-thaw cycles on the permeability and macrostructure of soils. Proc. Int. Symp. On Frozen Soil Impacts on Agricultural Range and Forest land. Special report, vol. 90-1. CRREL, Hanover, NH, USA, pp. 145155.

[8] Chen, F. H., 1988. Foundations on expansive soils. Elsevier.

[9] Chu, J., Varaskin, S., Klotz, U., Mengé, P., 2009. Construction Processes, Proceedings of the 17th International Conference on Soil Mechanics and Geotechnical Engineering, 5-9 October 2009, Alexandria, Egypt, M. Hamza et al. (Eds.), IOS Press, Amsterdam, Vol. 4, pp. 3006-3135.

[10] Eigenbrod, K.D., 1996. Effects of cyclic freezing and thawing on volume changes and permeabilities of soft fine-grained soils. Canadian Geotechnical Journal 33, 529-537.

[11] Erguler, Z.A., Ulusay, R., 2003. A simple test and predictive models for assessing swell potential of Ankara (Turkey) Clay. Engineering Geology 67, 331-352.

[12] Harvey, C.C., Murray, H.H., 1997. Industrial clays in the 21st century: a perspective of exploration, technology and utilization. Applied Clay Science 11, 285-310.
[13] Indiramma, P., Sudharani, C., Needhidasan, S., 2020. Utilization of fly ash and lime to stabilize the expansive soil and to sustain pollution free environment - An experimental study. Materials Today: Proceedings 22, 694-700.

[14] Ingles, O.G, Metcalf, J.B., 1977. Soil Stabilization Principles and Practice. 2nd ed, Australia Butterworths.

[15] Iskander, S.M., Zhao, R., Pathak, A., Gupta, A., Pruden, A., Novak, Z.T, He, Z., 2018. A review of landfill leachate induced ultraviolet quenching substances: Sources, characteristics, and treatment. Water Research 145, 297-311.

[16] Kalkan, E., 2003. The improvement of geotechnical properties of Oltu (Erzurum) clayey deposits for using them as barriers. Ph.D. Thesis (in Turkish), Ataturk University, Graduate School of Natural and Applied Science, Erzurum, Turkey.

[17] Kalkan, E., 2006. Utilization of red mud as a stabilization material for the preparation of clay liners. Engineering Geology 87, 220-229.

[18] Kalkan, E., 2009. Effects of silica fume on the geotechnical properties of fine-grained soils exposed to freeze and thaw. Cold Region Science and Technology 58, 130-135.

[19] Kalkan, E., 2011. Impact of Impact of wetting-drying cycles on swelling behavior of clayey soils modified by silica fume. Applied Clay Science 52 (4), 345-352.

[20] Kalkan, E., 2012. Effects of waste material-lime additive mixtures on mechanical properties of granular soils. Bulletin of Engineering Geology and the Environment 71, 99-103.

[21] Kalkan, E., 2018. Oltu Clay Deposits (Erzurum, NE Turkey) and Their Possible Usage Areas. International Journal of Innovative Research and Reviews 2(1), 25-30.

[22] Kalkan, E., Akbulut, S., 2004. The positive effects of silica fume on the permeability, swelling pressure and compressive strength of natural clay liners. Engineering Geology 73, 145-156.

[23] Kalkan, E., Bayraktutan, M.S., 2008. Geotechnical evaluation of Turkish clay deposits: a case study in Northern Turkey. Environmental Geology 55, 937-950.

[24] Kalkan, E., Yarbaş1, N., Bilici, Ö., 2019. Strength performance of stabilized clayey soils with quartzite material. International Journal of Earth Sciences Knowledge and Applications 1 (1), 1-5.

[25] Kalkan, E., Yarbaş1, N., Bilici, Ö., 2020. The Effects of Quartzite on the Swelling Behaviors of Compacted Clayey Soils. International Journal of Earth Sciences Knowledge and Applications 2 (2), 92-101.

[26] Kayabali, K., 1997. Engineering aspects of a novel landfill liner material: bentonite-amended natural zeolite. Engineering Geology 46 (2), 105-114.

[27] Keith, K.S., Murray, H.H., 1994. Clay liners and barriers, In: Carr, D.D. (Ed.), Industrial Minerals and Rocks, Sixth Edition. Society for Mining, Metallurgy and Exploration, Littleton, Colorado, pp. 435-452.

[28] Konrad, J.M., 2000. Hydraulic conductivity of kaolinitesilt mixtures subjected to closed-system freezing and 
thaw consolidation. Canadian Geotechnical Journal 37, 857-869.

[29] Lambe, T.W., Whitman, R.V., 1979. Soil Mechanics. SI version, New York, Wiley.

[30] Lasaki, A.G., Chenari, R.J., Sosahab, J.S., Jafarian, Y., 2018. Investigation of Strength Parameters of PVA Fiber-Reinforced Fly

[31] Ash-Soil Mixtures in Large-Scale Direct Shear Apparatus. Civil Engineering Journal 4 (11), 2618-2627.

[32] Lee, W., Bohra, N.C., Altschaeffl, A.G., White, T.D., 1995. Resilient modulus of cohesive soils and the effect of freeze-thaw. Canadian Geotechnical Journal 32, 559568.

[33] Manar, G., Hesham, B., Tareq, M., 2015. Soil Improvement Techniques. International Journal of Scientific \& Engineering Research 6 (12), 217-222.

[34] Murray, H.H., 2000. Traditional and new applications for kaolin, smectite, and palygorskite: a general overview. Applied Clay Science 17, 207-221.

[35] Naeini, S.A., Mahdavi, A., 2009. Effect of polymer on shear strength of silty sand. EJGE 14, 1-11.

[36] Naeini, S.A., Sadjadi, S.M., 2008. Effect of Waste Polymer Materials on Shear Strength of Unsaturated Clays. EJGE 13, 1-12.

[37] Nelson, J.D., Miller, D.J., 1992. Expansive Soils: Problems and Practice in Foundation and Pavement Engineering. John Wiley and Sons, Inc., New York.

[38] Pera, J., Boumaza, R., Ambroise, J., 1997. Development of pozzolanic pigment from red mud. Cement and Concrete Research 27 (10), 1513-1522.

[39] Porebska, M., 1994. Effects of freezing on the microstructure of compacted clays. Final Report. CRREL, Hanover, USA, p. 92.

[40] Prabakar, J., Sridhar, R.S., 2002. Effect of random inclusion of sisal fibre on strength behavior of soil. Construction and Building Materials 16, 123-131.

[41] Puppala, A.J., Musenda, C., 1998. Investigation of geofiber reinforcement method on strength, swell, and shrinkage characteristic of soils. Presented at Fifth International Conference on Composites Engineering, Las Vegas.
[42] Sabtan, A.A., 2005. Geotechnical properties of expensive clay shale in Tabuk, Saudi Arabia. Journal of Asian Earth Science 25, 747-757.

[43] Sandra, T., Jeffrey, C.E., 1992. The effects of filler and admixtures on grout performance. Grouting, Soil Improvement, and Geosynthetics. Geotechnical Engineering Division of ASCE, USA 1, 337-349.

[44] Simonsen, E., Isacsson, U., 2001. Soil behavior during freezing and thawing using variable and constant confining pressure triaxial tests. Canadian Geotechnical Journal 38, 863-875.

[45] Simonsen, E., Janoo, V.C., Isacsson, U., 2002. Resilient properties of unbound road materials during seasonal frost conditions. Journal of Cold Regions Engineering ASCE 16, 28-50.

[46] Viklander, P., Eigenbrod, D., 2000. Stone movements and permeability changes in till caused by freezing and thawing. Cold Regions Science and Technology 31, 151162.

[47] Yang, M., Yao, T., Gou, X., Koike, T., He, Y., 2003. The soil moisture distribution, thawing-freezing processes and their effects on the seasonal transition on the Qinghai-Xizang (Tibetan) plateau. Journal of Asian Earth Sciences 21, 457-465.

[48] Yarbaş1, N., Kalkan E., 2019. The Stabilization of Sandy Soils by Using the Plastic Bottle Waste. International Journal of Advance Engineering and Research Development 6 (11), 140-144.

[49] Yarbaş1, N., Kalkan E., 2020. The Mechanical Performance of Clayey Soils Reinforced with Waste PET Fibers. International Journal of Earth Sciences Knowledge and Applications, 2(1) 19-26.

[50] Yarbaş1, N., Kalkan, E., 2021. Freeze-Thaw Resistance of Fine-Grained Soils Stabilized with Waste Material Mixtures. International Journal of Science and Engineering Applications 9 (12), 158-163.

[51] Yong, R.N., Boonsinsuk, P., Yin, C.W.P., 1985. Alteration of soil behavior after cyclic freezing and thawing. Proc. 4th Int. Symp. Ground Freezing, Sapporo, pp. 187-195.

[52] Zhang, S., Lai, Y., Zhang, X., Pu, Y., Yu, W., 2004. Study on the damage propagation of surrounding rock from a cold-region tunnel under freeze-thaw cycle condition. Tunnelling and Underground Space Technology 19 (3), 295-302. 